\title{
Electrochemical Incineration of Organic Pollutants for Wastewater Treatment: Past, Present and Prospect
}

\author{
Songsak Klamklang1, Hugues Vergnes², \\ Kejvalee Pruksathorn ${ }^{3}$ and Somsak Damronglerd ${ }^{3}$ \\ ${ }^{1}$ Technology Center, SCG Chemicals Co., Ltd., Siam Cement Group (SCG), Bangkok \\ ${ }^{2}$ Laboratoire de Génie Chimique, UMR CNRS 5503, BP 84234, INP-ENSIACET \\ ${ }^{3}$ Department of Chemical Technology, Faculty of Science, \\ Chulalongkorn University Bangkok \\ 1,3Thailand \\ ${ }^{2}$ France
}

\section{Introduction}

Water is a combination of two parts, hydrogen and oxygen as $\mathrm{H}_{2} \mathrm{O}$. However, pure water is only produced in a laboratory, water in general is not pure composition of hydrogen and oxygen. Eventhough, distilled water still has measurable quantities of various substances such as ions, mineral or organic compounds (http://www.environmental-center.com). These substances should be considered as the impurities that dissolved into water during flow through hydraulic pathway. Nowadays, there are some increasing on both population and consumption of natural resources to serve endless needs. Water is most important resource and becomes limited of use due to contamination from discharge of both domestic and industry. The discharge of domestic wastewater contains a large amount of organic pollutants. Industry also contributes substantial amounts of organic pollutants. However, some organic substrates discharged from industry contain a high toxicity and refractory organic pollutants.

Figure 1 presents the example of a partially closed water cycle. In the cycle the organic pollutants are neither removed by sorption nor biodegradation. Nevertheless, there are some organic pollutants pass all barriers such as wastewater treatment or underground passage and appear in raw waters used for drinking water production. The other group of organic pollutants may originate from consumer products used in household, pesticides applied in agriculture or chemicals used in industry (Reemtsma \& Jekel,2006).

Wastewater treatment consists of applying known technology to improve or upgrade the quality of a wastewater. Usually wastewater treatment will involve collecting the wastewater in a central, segregated location and subjecting the wastewater to various treatment processes (Hanze et al., 1995). Wastewater treatment can be organized or categorized by the nature of the treatment process operation being used such as physical, chemical or biological treatment. Biological treatment of polluted water is the most economical process and commonly used for the elimination of degradable organic 
pollutants present in wastewater. However, situation fully differs when the wastewater contains toxic and refractory substrates, biological treatment may not suitable tool for treatment of contaminated wastewater (Grimmet al., 1998).

This chapter review related technologies and case studies of application of electrochemical incineration in industrial and restaurant wastewater treatment.

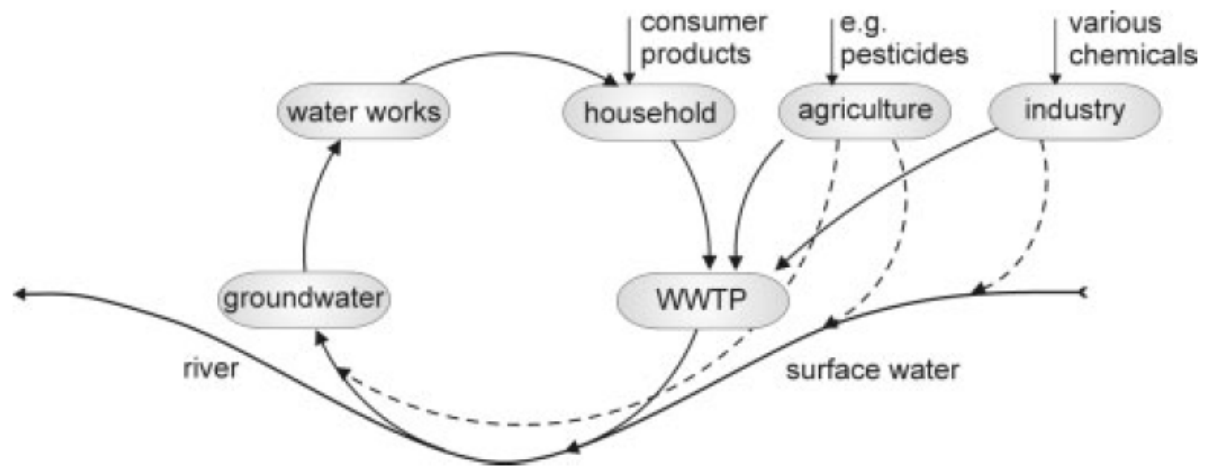

Fig. 1. Schematic of water cycle (Reemtsma \& Jekel,2006).

\section{Electrochemical incineration}

Electrochemistry is a clean, versatile and powerful tool for the destruction of organic pollutants in wastewater. Electrochemical oxidation of organic compounds in aqueous solution is an anodic process occurring in the potential region of water discharge to produce oxygen (Kapalka et al., 2009).

Two different pathways are described in the literatures for the anode oxidation of undesired organic pollutants (Grimm et al., 1998). Electrochemical conversion transforms only the toxic pollutants refractory to biological treatments into biocompatible organics, so that biological treatment is still required after the electrochemical oxidation (Comninellis., 1994). The ideal electrode material which can be used in the electrochemical conversion method must have high electrochemical activity for aromatic ring opening and low electrochemical activity for further oxidation of the aliphatic carboxylic acids which are in general biocompatible (Comninellis., 1994).

Electrochemical incineration or combustion is method completely oxidizes the organic pollutants to $\mathrm{CO}_{2}$ by physisorbed hydroxyl radicals. In this case, the electrode material must have high electrocatalytic activity towards the electrochemical oxidation of organics to $\mathrm{CO}_{2}$ and $\mathrm{H}_{2} \mathrm{O}$ (Comninellis., 1994).

\subsection{Mechanism of electrochemical incineration}

Study on electrochemical oxidation for wastewater treatment goes back to the 19th century, when electrochemical decomposition of cyanide was investigated (Kuhn., 1971). Extensive investigation of this technology commenced since the late 1970s (Chen., 2004). During the last two decades, research works have been focused on the efficiency in oxidizing various pollutants on different electrodes, improvement of the electrocatalytic activity and electrochemical stability of electrode materials, investigation of factors affecting the process performance, and exploration of the mechanisms and kinetics of pollutant degradation. 
Experimental investigations focus mostly on the behaviors of anodic materials, the effect of cathodic materials was not investigated extensively although Azzam et al. (Azzam et al, 1999) have found a considerable influence of the counter electrode material in the anodic destruction of 4-chlorophenol.

Comninellis (Comninellis., 1994) has presented the mechanism of electrochemical oxidation and it was used as fundamental of electrochemical wastewater treatment. According to the electrochemical conversion and combustion of organics is presented on metal oxide anode $\left(\mathrm{MO}_{\mathrm{x}}\right) . \mathrm{H}_{2} \mathrm{O}$ in acid or $\mathrm{OH}^{-}$in alkali solution is discharged at the anode to produce adsorbed hydroxyl radical according to the equation (1).

$$
\mathrm{MO}_{\mathrm{X}}+\mathrm{H}_{2} \mathrm{O} \stackrel{\mathrm{k}_{1}}{\longrightarrow} \mathrm{MO}_{\mathrm{x}}\left({ }^{\bullet} \mathrm{OH}\right)+\mathrm{H}^{+}+\mathrm{e}^{-}
$$

$\mathrm{k}_{1}=$ Electrochemical rate constant for $\mathrm{H}_{2} \mathrm{O}$ discharge

Secondly, the adsorbed hydroxyl radicals may interact with the oxygen already present in the metal oxide anode with possible transition of oxygen from the adsorbed hydroxyl radical to the lattice of the metal oxide anode forming the so-called higher oxide $\left(\mathrm{MO}_{\mathrm{X}+1}\right)$ as represented in equation (2).

$$
\mathrm{MO}_{\mathrm{X}}(\cdot \mathrm{OH}) \stackrel{\mathrm{k}_{2}}{\longrightarrow} \mathrm{MO}_{\mathrm{X}+1}+\mathrm{H}^{+}+\mathrm{e}^{-}
$$

$\mathrm{k}_{2}=$ Electrochemical rate constant for transition of oxygen into oxide lattice

Thus, It could be considered that at the anode surface, two states of active oxygen can be presented in physisorbed active oxygen (adsorbed hydroxyl radicals, $\cdot \mathrm{OH}$ ) and chemisorbed active oxygen (oxygen in the oxide lattice, $\mathrm{MO}_{\mathrm{x}+1}$ ).

In the absence of any oxidizable organics, the physisorbed and chemisorbed active oxygen produce dioxygen according to the equation (3) and (4).

$$
\mathrm{MO}_{\mathrm{x}}(\cdot \mathrm{OH}) \stackrel{\mathrm{k}_{\mathrm{o}}}{\longrightarrow} \frac{1}{2} \mathrm{O}_{2}+\mathrm{H}^{+}+\mathrm{e}^{-}+\mathrm{MO}_{\mathrm{x}}
$$

$\mathrm{k}_{0}=$ Electrochemical rate constant for $\mathrm{O}_{2}$ evolution

$$
\mathrm{MO}_{\mathrm{X}+1} \stackrel{\mathrm{k}_{\mathrm{d}}}{\longrightarrow} \mathrm{MO}_{\mathrm{X}}+\frac{1}{2} \mathrm{O}_{2}
$$

$\mathrm{k}_{\mathrm{d}}=$ Electrochemical rate constant for $\mathrm{O}_{2}$ evolution

In the presence of oxidizable organics, it is speculated that the physisorbed active oxygen $(\cdot \mathrm{OH})$ should cause predominantly the complete combustion of organics according to equation (5), and chemisorbed active oxygen $\left(\mathrm{MO}_{\mathrm{x}+1}\right)$ participate in the formation of selective oxidation products as represented in equation (6).

Complete combustion:

$$
\mathrm{R}+\mathrm{MO}_{\mathrm{x}}(\cdot \mathrm{OH}) \stackrel{\mathrm{k}_{\mathrm{c}}}{\longrightarrow} \mathrm{CO}_{2}+\mathrm{zH}^{+}+\mathrm{ze}^{-}+\mathrm{MO}_{\mathrm{x}}
$$

$\mathrm{k}_{\mathrm{c}}=$ Electrochemical rate constant for the combustion of organics

Selective oxidation:

$$
\mathrm{R}+\mathrm{MO}_{\mathrm{X}+1} \stackrel{\mathrm{k}_{\mathrm{s}}}{\longrightarrow} \mathrm{RO}+\mathrm{MO}_{\mathrm{x}}
$$

$\mathrm{k}_{\mathrm{s}}=$ Electrochemical rate constant for the selective oxidation of organics 


\subsection{Electrochemical incineration performance}

There are several researchers' work on the parameters that affect on the electrochemical oxidation process efficiency. In this topic, some important parameters for electrochemical treatment by electrochemical incineration have been reviewed.

\section{Support materials}

Vercesi (Vercesi et al, 1991) worked on searching for a good Dimensionally Stable Electrode (DSA) that has long service life for $\mathrm{O}_{2}$-evolution based on the effects of support materials. Titanium, tantalum, zirconium, niobium and some of their alloys were used as support materials on the performance of $\mathrm{IrO}_{2}-\mathrm{Ta}_{2} \mathrm{O}_{5}$ coated electrodes. The thermal behavior and oxygen affinity sequence of the metals, in relation to the electrode preparation procedure, were determined thermogravimetrically. The electrochemical corrosion of base metals was represented in Figure 2, the tantalum-based materials presented the highest stability with the minimum corrosion rate. The chemical and electrochemical stability of the base metals was found to be directly related to the service life of the electrode, measured in $30 \% \mathrm{H}_{2} \mathrm{SO}_{4}$ at $80^{\circ} \mathrm{C}$ and $750 \mathrm{~mA} / \mathrm{cm}^{2}$. Tantalum-based electrodes represented the highest service life, $1700 \mathrm{~h}$ and $120 \mathrm{~h}$ for titanium-based electrodes.

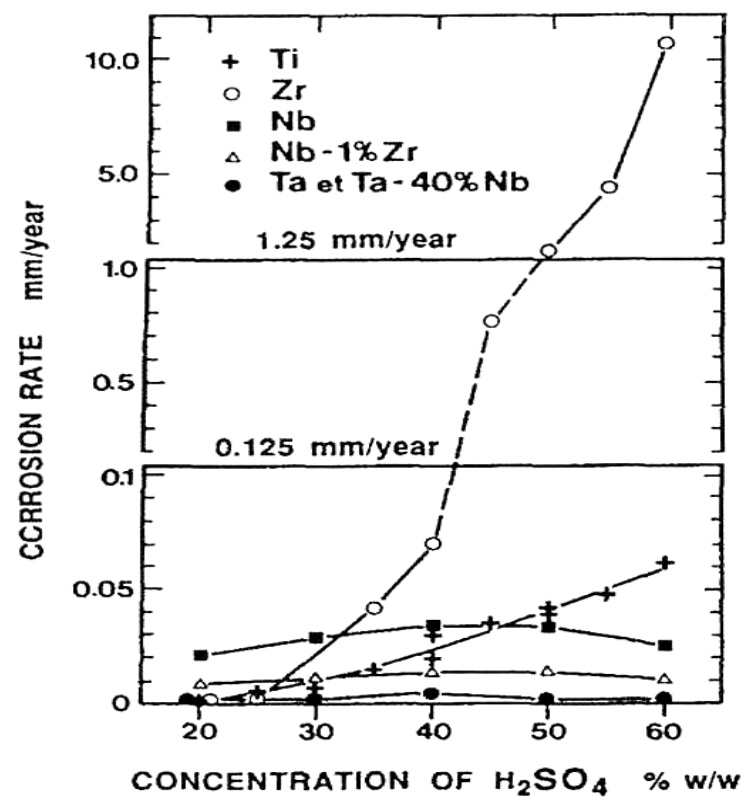

Fig. 2. Electrochemical corrosion rate of base metals as a function of $\mathrm{H}_{2} \mathrm{SO}_{4}$ concentration at anode potential of $2 \mathrm{~V} / \mathrm{SCE}$ (Vercesi et al, 1991).

\section{Coating materials}

The active coating materials of electrodes are very important for pollutants degradation in electrochemical oxidation process. It could point the project to be benefit or insolvent. The coating enables the electrical charge transport between the base metal and the electrode/electrolyte interface. It must have high chemical and electrochemical stability and able to catalyse the desired electrochemical reaction. 
There are some works focusing on the active coating materials for electrochemical degradation of organic pollutants in wastewater. Comninellis (Comninellis \& Vercesil, 1991) found that the $\mathrm{Ta}_{2} \mathrm{O}_{5}$-doped $\mathrm{IrO}_{2}$ represented the highest service life. However, the same author (Comninellis., 1994) proposed in 1994 that the mechanism of electrochemical oxidation of organic pollutant on $\mathrm{IrO}_{2}$ electrode was the electrochemical selective oxidation while that on $\mathrm{SnO}_{2}$ electrode was the electrochemical combustion. On $\mathrm{SnO}_{2}$ electrode, the organic pollutants were oxidized to $\mathrm{CO}_{2}$ and water. The $\mathrm{SnO}_{2}$ electrode presents the highest current efficiency. Because of its highest oxidation state which contains excess oxygen in the oxide lattice as possible. At $\mathrm{SnO}_{2}$ surface, the hydroxyl radicals are accumulated and favor the combustion of organics while the other oxides having a high concentration of oxygen vacancies and can favor selective oxidation of organics more than combustion.

Not only $\mathrm{SnO}_{2}$ electrode has the good attractive to be used as electrode for wastewater treatment in electrochemical oxidation, the diamond thin films have been widely used in electrochemical studies due to the unique properties like chemical stability, large potential range and mechanical resistance. Their applications embrace the electroanalysis, electrosynthesis, fuel cell and the organic pollutant degradation in wastewater (Diniz et al, 2003). Some studies showed that conducting diamond electrodes could be grown by energyassisted (plasma or hot-filament) chemical vapor deposition on several substrates, such as silicon, titanium, niobium, tantalum, molybdenum, glassy carbon. Although all these substrates are currently used, they still have some drawbacks. In fact, a silicon substrate is very brittle, $\mathrm{Nb}, \mathrm{Ta}, \mathrm{W}$ are too expensive and the stability of the diamond layer deposited on the Ti substrate is still not satisfactory, because cracks may appear and cause the detachment of the diamond film during long-term electrolysis (Panizza \& Cerisola, 2005). The organic compound electrochemical oxidation efficiency strongly depends on the used anode material and diamond is very interesting due to its superior properties (Diniz et al, 2003). In recent years, there are some publications on the application of diamond electrode for wastewater treatment (Diniz et al, 2003, Lissens., 2003). However, the application of diamond electrode for organic pollutant degradation still limited due to the cost of diamond electrode is too expensive.

pH

Normally, the efficiency of the oxidation of organics tends to be superior in alkaline solution. That also holds for the anodic treatment using standard electrode materials. The wastewater accessible to treatment process has any $\mathrm{pH}$ and $\mathrm{pH}$ adjustment before treatment to the more favorable value above 7 will be too expensive. Moreover, Stuki (Stucki et al, 1991) proved that on $\mathrm{SnO}_{2}$ electrodes, the degradation of benzoic acid was $\mathrm{pH}$ independent. Cañizares (Cañizares et al, 2004) proposed that the $\mathrm{pH}$ does not influence in the global oxidation rate even if initial oxidation rate was higher in alkaline media. However, after the galvanostatic method development, the oxidation rate in acidic media surpasses those in the alkaline media because the accumulation of oxalic acid in alkaline media was higher than that in acidic media, due to its lower oxidazability at alkaline conditions.

\section{Current density}

The effect of current density was studied many times, Comninellis (Comninellis \& Nerini, 1995) found that the degradation of phenol was independent from the current density and that the phenol elimination depends only on the specific electrical charge. Almost complete phenol elimination can be archived after the passage of an electrical charge of 17-20 $\mathrm{Ah} / \mathrm{dm}^{3}$. 
The higher current densities increase the initial reaction rate $(\mathrm{dCOD} / \mathrm{dt})(\mathrm{COD}:$ Chemical Oxygen Demand) but decrease lightly the initial efficiencies of the process $(\mathrm{dCOD} / \mathrm{dQ})(\mathrm{Q}$ : charge). Nevertheless, both treatments end nearly at the same charge passed. This behavior is a characteristic of electrochemical systems in which both direct and mediated oxidation reactions play an important role. But the low current density experiment achieves initially a higher mineralization rate. This fact can be easily explained that the amount of oxalic acid, that is an end of chain product and difficult to destroy, accumulated in the high current density experiment is greater than those obtained in the low current density experiments (Cañizares et al, 2004).

Although, the current density might not affect on the kinetic of surface electrochemical oxidation of organic pollutant, it also enhances the production of bulk chemicals, which may contribute to the degradation process through parallel reaction schemes.

Klamklang (Klamklang, 2006, Klamklang, 2007 and Klamklang et al, 2010) has found that increasing current density from 5 to $10 \mathrm{~mA} / \mathrm{cm}^{2}$, leads to less degradation rate of oxalic acid by electrochemical oxidation. This behavior is characteristic of mass transfer-controlled processes (Kesselman, 1997). In such systems, the increase of current density cannot increase the organic removal efficiency at the electrode, but only favors oxygen evolution as the anodic side reaction which hides the electrode and prevents contact between hydroxyl radicals and organic pollutants. When the system does not generate only adsorbed hydroxyl radicals or other active oxygen, the decrease of organic pollutant removal efficiency is observed.

\section{Temperature}

An increase in the temperature leads to more efficient processes by global oxidation. While direct oxidation processes remain almost unaffected by temperature, this fact may be explained in terms of the presence of inorganic electrogenerated reagents. The oxidation carried out by these redox reagents is a chemical reaction. Consequently, its rate normally increases with temperature. But the oxidation process can be carried out either at the electrode surface and by electrogenerated reagents-mainly hypochlorite and peroxodisulphates. However, the new organic intermediates are not formed with the increase of temperature, indicating that the process mechanisms do not vary with temperature (Cañizares et al, 2004).

\subsection{Electrocatalytic electrodes}

Electrochemical degradation of organic pollutants in the wastewater needs specific electrodes. Couper (Couper et al, 1990) has reviewed some properties of typical substrates used as electrocatalytic electrodes and report that electrode must have low voltage drop through the substrates and substrate-solvent interface. Many metallic electrodes could answer these criteria and many alloys can also be used as good composite electrodes covered with an active layer and a long service life of electrodes.

The complexity of electrode behaviors and our lack of detailed insights make it impossible to select the optimum electrode for a given process on a theoretical basis. Instead, an empirical approach must be used. The initial selection is based on process experience, and this is then tested and refined during an extensive development program. Indeed, it is very difficult to predict the success of an electrode material or to define its lifetime without extended studies under realistic process conditions. Accelerated testing is rarely satisfactory except to indicate catastrophic failure.

There are some general guidelines to assist the choice of an electrode material; 


\section{Physical stability}

The electrode material must have adequate mechanical strength, must not be prone to erosion by the electrolyte, reactants, or products, and must be resistant to cracking.

\section{Chemical stability}

The electrode material must be resistant to corrosion, unwanted oxide or hydride formation, and the deposition of inhibiting organic films under all conditions (e.g., potential and temperature) experienced by the electrode.

\section{Suitable physical form}

It must be possible to fabricate the material into the form demanded by the reactor design, to facilitate sound electrical connections, and to permit easy installation and replacement at a variety of scales. The shape and design of the electrode may take into account the separation of products, including the disengagement of gases or solids.

\section{Rate and product selectivity}

The electrode material must support the desired reaction and, in some cases, significant electrocatalytic properties are essential. The electrode material must promote the desired chemical change while inhibiting all competing chemical changes.

\section{Electrical conductivity}

This must be reasonably high throughout the electrode system including the current feeder, electrode connections, and the entire electrode surface exposed to the electrolyte. Only in this fashion it is possible to obtain a uniform current and potential distribution as well as to avoid voltage losses leading to energy inefficiencies.

\section{Cost and lifetime}

A reasonable and reproducible performance including a lifetime probably extending over several years must be achieved for an acceptable initial investment.

It is important to note that the choice of working and counter electrodes cannot be made independently since the chemistry at each has consequences to the solution composition throughout the cell. Indeed, the selection of electrode material and its form must be an integrated decision within the prospective of the cell and process design. In some cases such as the manufacture of pharmaceutical products, the electrodes and their compounds must have a low toxicity.

This section has reviewed the ways in which the choice of electrode material influences the design of electrochemical reactors and process performance.

\section{Energy Consumption}

The specific energy consumption should be minimized in order to minimize the power costs. In general, the total power requirement has contributions for both electrolysis and movement of either the solution or the electrode. The design of electrodes and cell has an important role in reducing each of these components. Thus, a very open flow-through porous electrode will have a low pressure drop associated with it, giving rise to modest pumping costs and facilitating reactor sealing. A high surface area electrode which itself a turbulence promoter in bed electrode, will give rise to a moderately high mass transfer coefficient and active area without the need for high flow rates through the cell; the pumping cost will again be moderately low.

The direct electrolytic power could be minimized by

- Obtaining a current efficiency approaching 1.0

- Minimizing the cell voltage.

It is therefore important to select the electrode material and operating conditions so as to maintain a high current efficiency. This also assists the operation of the process by reducing the amount of product purification that is necessary and/or byproducts that must be handled. 
The cell voltage is a function of the reversible cell voltage, the over-potentials at the two electrodes, and ohmic drops in the electrolyte, the electrodes, busbars etc., and any separator in the cell. Again, the maintenance of a low cell voltage demands attention to the design of both electrodes and cell. Where possible, the following features should be included:

- The counter electrode reaction should be chosen so as to minimize the reversible cell voltage. This requires the availability of a suitably stable electrode material.

- The over-potentials at both electrodes should be minimized by the use of electrocatalysts.

- The electrodes, current feeders, and connectors should be made from highly conducting materials to lower ohmic drops.

- The electrodes should facilitate low $I R$ drop in the electrolyte by, for example, allowing efficient gas disengagement and passage out of the interelectrode gap. Meshes as well as louvred and lantern blade electrodes can be used.

- Electrode and cell design should allow a small interelectrode or electrode membrane gap. In the limit, the electrode may touch the membrane as in zero-gap or solid polymer electrolyte cells.

- A separator should be avoided by suitable selection of the counter electrode chemistry or, if essential, a thin conductive membrane should be used.

\section{Current efficiency}

Current efficiency is the fraction of the total charge passed that is used in the formation of the desired product. This can be a strong function of electrode material, e.g., because of differences in the rate of hydrogen evolution as a competing reaction. Competing reactions can also lead to the corrosion and/or erosion of the electrode material as well changes to the electrode (e.g., by formation of a hydroxide or oxide or the deposition of another metal onto the surface).

\section{Material Yield}

This is the fraction of the starting material that is converted into the desired product. This is also dependent on electrode material in many cases. Values less than one indicate byproducts and hence perhaps the need to introduce additional purification steps that inevitably increases the complexity of the overall process and costs.

\section{Space-Time Yield}

One of the most valuable statements of reactor performance is the space-time yield or weight of product per unit time per unit volume of reactor. It is determined by the current density, the current efficiency, and the area of electrode per unit volume of cell, all dependent on the electrode material and its form. Commonly, the cell is operated in conditions where the electrode reaction is mass-transport controlled (especially when a high fractional conversion is desirable or when the concentration of reactant is limited by solubility or process considerations. Then, the current density is determined by the concentration of reactant and the mass transport condition. The latter is therefore frequently enhanced by the use of high flow rates, turbulence promoters, and/or electrode movement.

The current is proportional to the active electrode area in the cell. A compact cell design requires a high area per unit cell volume. This suggests the use of a three-dimensional electrode but such electrodes make it difficult to maintain a uniform fluid flow and electrode potential, i.e., to control the reaction environment. Hence, the use of porous, flowthrough electrodes often involves a trade-off between enhanced electrode area and material yield and/or current efficiency. 


\section{Other Factors}

Of course, other factors are important in the design of electrodes and cells. These include cost, safety, ease of maintenance, and convenience to use. It is also essential that the performance of the electrodes is maintained throughout the projected operating life of the cell, maybe several years. Examples of problems that frequently arise include (a) deposition onto cathode surfaces of hydrogen evolution catalysts due to trace transitional metal ions in the electrolyte and (b) poisoning of $\mathrm{PbO}_{2}$ anodes by organic molecules leading to enhanced corrosion as well as oxygen evolution.

\section{Application of electrochemical incineration in wastewater treatment}

\subsection{Electrochemical incineration for restaurant wastewater treatment}

There are a lot of restaurants, cafeterias and food centers in the big cities, which everyday make large amounts of wastewater. Generally, there is unavailable of on-site treatment for each restaurant. The direct discharge of wastewater from these restaurants and food shops to the drainage system is a huge problem to the municipal wastewater collection and treatment works. The oil and grease contained in the wastewater aggregate and foul the sewer system and generate an unpleasant odor (Chen et al, 2000).

Basically, restaurant wastewater treatment facilities must be highly efficient in removing oil and grease, cause no food contamination and be compact size. Low capital and operating costs are important because profit margins of most restaurants are small. In addition, the technology has to be simple so that it can be operated easily either by a chef or a waiter (Chen et al, 2000).

Conventional biological processes are therefore ruled out due to the requirement of large space, long residence time and skilled technicians. Chemical coagulation/settlement is not practicable because of the low efficiency in removing light and finely dispersed oil particles and possible contamination of foods by chemicals. The G-bag approach, which uses a bag of absorbent to capture the pollutants and degrade the pollutants with the immobilized microorganisms on the absorbent, seems to be a good alternative only if the system can be designed as simple and free from fouling (Chen et al, 2000).

In this work, the treatment of restaurant wastewater by electrochemical incineration is obtained with continuous electrochemical oxidation system described elsewhere Klamklang (Klamklang, 2006, Klamklang, 2007 and Klamklang et al, 2010). A simple three-electrode electrochemical reactor with $18 \mathrm{ml}$ of capacity with using $\mathrm{Ti} / \mathrm{SnO}_{2}$ electrodes as anode, the 316L stainless steel was used as cathode. The feed solution was fed to the reactor by peristaltic pump and the effluent was collected at sample trap. The apparatus is presented in Figure 3. (Klamklang, 2006). The operating conditions were represented in Table 1.

\begin{tabular}{|l|c|}
\hline Parameter & Operating condition \\
\hline Current density & $5-10 \mathrm{~mA} / \mathrm{cm}^{2}$ \\
$\mathrm{SnO}_{2}$ film thickness & $1.8-3.6 \mathrm{micron}$ \\
Residence time & $2-3 \mathrm{hr}$ \\
Elapse time & $24 \mathrm{hr}$ \\
Stirring & $300 \mathrm{rpm}$ \\
\hline
\end{tabular}

Table 1. Operating conditions for continuous electrochemical oxidation. 


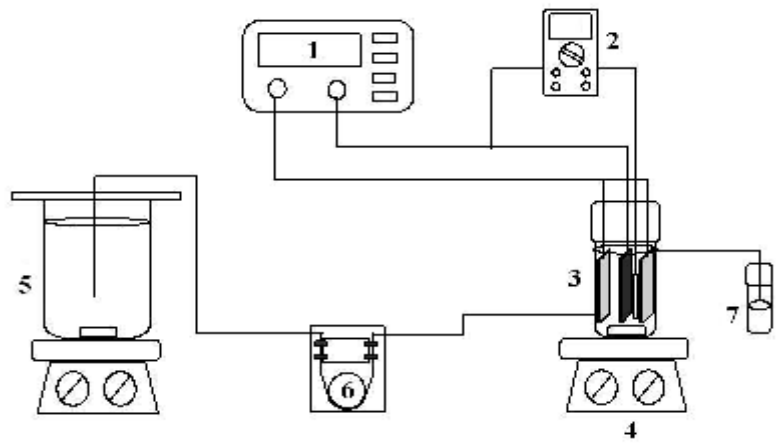

1) Power supply, 2) Voltmeter, 3) Electrochemical reactor set, 4) Magnetic stirrer, 5) Feed reservoir, 6) Peristaltic pump, 7) Sample trap

Fig. 3. Schematic diagram of continuous electrochemical oxidation apparatus.

The experiments performed in a continuous mixed flow reactor were carried out for the determination of the effects of the current density, residence time and $\mathrm{SnO}_{2}$ film thickness on organic pollutant degradation. Due to the very small electrode area and easy to observe the change of Total Organic Carbon (TOC), the wastewater, which feed to the system, was diluted to around $140 \mathrm{mg}$ TOC/L. The investigated current densities were 5 and $10 \mathrm{~mA} / \mathrm{cm}^{2}$ and residence times were 2 and $3 \mathrm{hr}$.

\section{Influence of current density}

The influence of current density in continuous mixed flow experiments is presented in part A of the Figure 4. The electrochemical degradation of organic pollutants presented in actual restaurant wastewater takes place slowly and its TOC removal efficiency presented in part B of this figure is higher at lower current density. The gain in efficiency being overwhelmed by the lower current values applied. This result may not be surprising on the basis of the previously discussed influence of current density in batch experiments, which indicated to a weak behavior for the characteristic of diffusion-controlled processes. Increase in current density cannot increase the organic removal efficiency at the electrode, but only favours the anodic side reaction which decreased the organic pollutant removal efficiency. It agrees with Figures 5 (A) and (B) that the destruction of organic pollutants in term of Chemical Oxygen Demand (COD) was decreased with increasing of the current density from 5 to $10 \mathrm{~mA} / \mathrm{cm}^{2}$. The equilibrium efficiencies of both TOC and COD removal were $62 \%$ when current density was $5 \mathrm{~mA} / \mathrm{cm}^{2}$, while their removal efficiencies were $47 \%$ when the current density was 10 $\mathrm{mA} / \mathrm{cm}^{2}$.

\section{Influence of residence time}

The presented results in batch experiments show that the increasing of residence time after first $2 \mathrm{hr}$ was not greatly affect on the organic pollutant degradation efficiency due to the change reaction order from zero-order to first-order reaction with reduction of TOC. However, it would be of practical interest to test how much an increase or decrease in the wastewater flow rate affects the TOC removal of the restaurant wastewater. This is demonstrated in Figures 6 and 7. Because of fixed total volume of the continuous mixed flow reactor at $18 \mathrm{ml}$, an increase in the wastewater flow rate from 0.10 to $0.15 \mathrm{ml} / \mathrm{min}$ translates to a proportional decrease in the wastewater hydraulic residence time from 3 to $2 \mathrm{hr}$. 

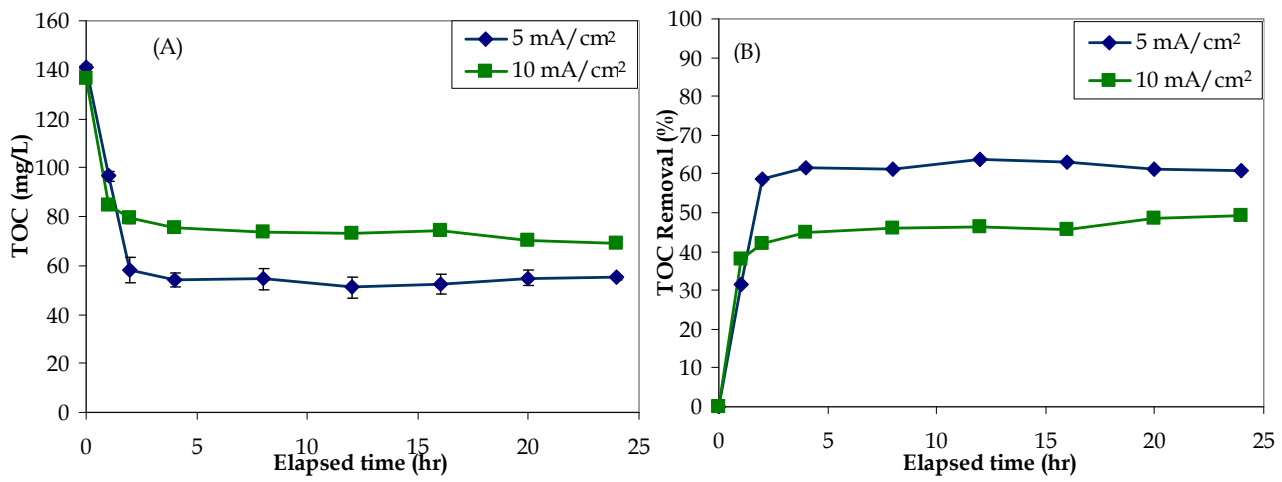

Fig. 4. Effect of current density on TOC removal (A) and TOC removal efficiency (B) in continuous restaurant wastewater treatment by using of $\mathrm{SnO}_{2} / \mathrm{Ir} / \mathrm{Ti}$ electrode, $\mathrm{SnO}_{2}$ thickness of 1.8 micron.
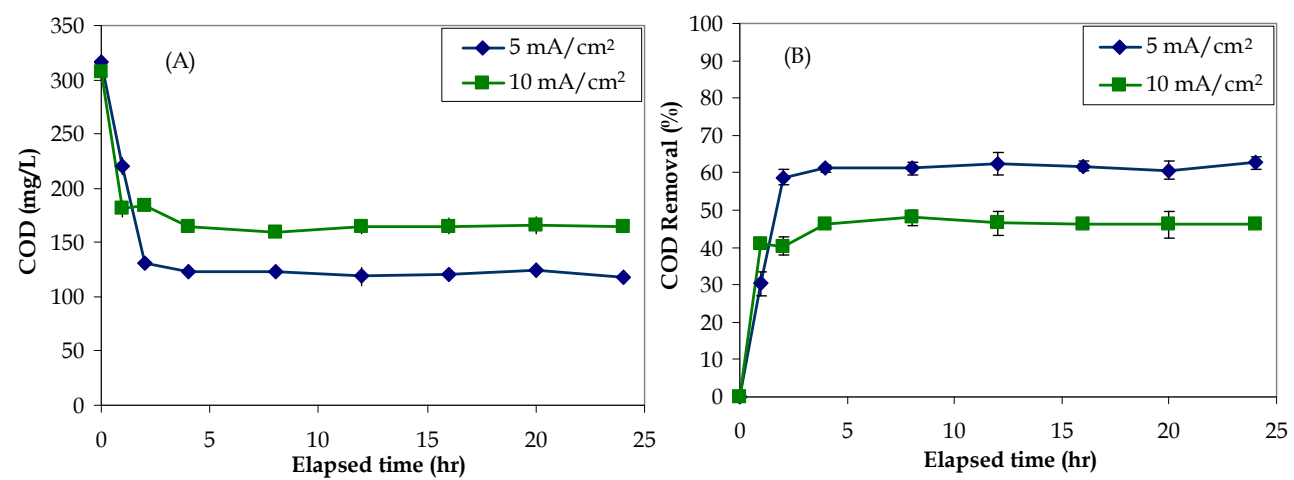

Fig. 5. Effect of current density on COD removal (A) and COD removal efficiency (B) in continuous restaurant wastewater treatment by using of $\mathrm{SnO}_{2} / \mathrm{Ir} / \mathrm{Ti}$ electrode, $\mathrm{SnO}_{2}$ thickness of 1.8 micron.

Normally, a reduction in residence time would expectedly lead to a decrease in the wastewater TOC removal. But, in this case, increasing of residence time does not proportionally increase TOC removal. As seen in Figure 6 ((A) and (B)), the TOC removal increases from around 55 to $62 \%$ with the increase in the residence time from 2 to $3 \mathrm{hr}$. These results were also observed in the removal of COD and represented in Figure 7 (A) and (B). The COD removal increased from around 54 to $62 \%$ with the increase in residence time from 2 to $3 \mathrm{hr}$.

It could be explained by the increasing of residence time from 2 to $3 \mathrm{hr}$ has not strongly affected on the TOC and COD removal due to the fast reaction with zero-order reaction occurred in the first $2 \mathrm{hr}$. Then, the reaction was changed to the slower step with the firstorder reaction as we found in the batch experiments.

Hence, it would be more economical to operate the electrochemical treatment at a lower residence time as long as the pollutant concentration of the treated wastewater meets the safe discharge requirement. 

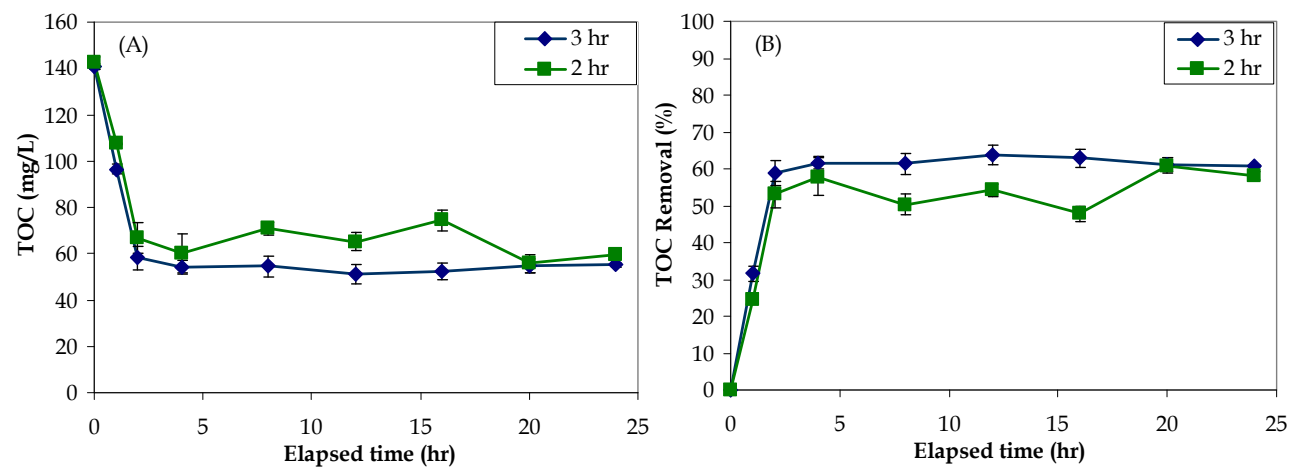

Fig. 6. Effect of residence time on TOC removal (A) and TOC removal efficiency (B) in continuous restaurant wastewater treatment by using of $\mathrm{SnO}_{2} / \mathrm{Ir} / \mathrm{Ti}$ electrode, $\mathrm{SnO}_{2}$ thickness of 1.8 micron and current density $5 \mathrm{~mA} / \mathrm{cm}^{2}$.
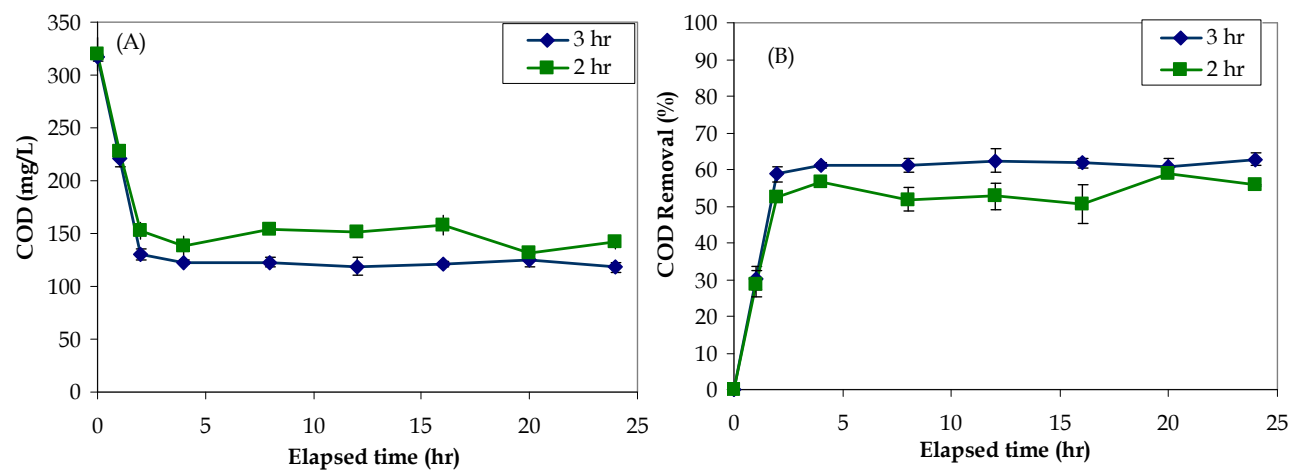

Fig. 7. Effect of residence time on COD removal (A) and on COD removal efficiency (B) in continuous restaurant wastewater treatment by using of $\mathrm{SnO}_{2} / \mathrm{Ir} / \mathrm{Ti}$ electrode, $\mathrm{SnO}_{2}$ thickness of 1.8 micron and current density of $5 \mathrm{~mA} / \mathrm{cm}^{2}$.

\section{Influence of $\mathrm{SnO}_{2}$ active layer thickness}

Figures 8 (A) and (B) represent the effect of $\mathrm{SnO}_{2}$ film thickness on the TOC degradation performance in continuous electrochemical oxidation. Similar to the pollutant degradation of organic pollutant in batch experiment, it shows that the $\mathrm{SnO}_{2}$ active layer thickness was not a great influence on the TOC removal efficiency because the adsorbed hydroxyl radicals for organic pollutant degradation were produced only at the surface of electrode. However, the TOC removal efficiency was around $62 \%$ with the 1.8 micron of $\mathrm{SnO}_{2}$ active layer while the efficiency was reduced to $51 \%$ with the $\mathrm{SnO}_{2}$ active layer thickness of 3.6 micron. It agrees with the removal of COD from restaurant wastewater as presented in Figure 9. The COD removal efficiency was $62 \%$ when the thickness of $\mathrm{SnO}_{2}$ active layer was 1.8 micron. However, the efficiency was decreased to $50 \%$ when the thickness of $\mathrm{SnO}_{2}$ active layer was 3.6 micron. It should be explained that thickness of 3.6 micron has bigger grain size that leads to a less surface area; therefore, the reaction kinetic was decreased as found previously in the batch experiment. 

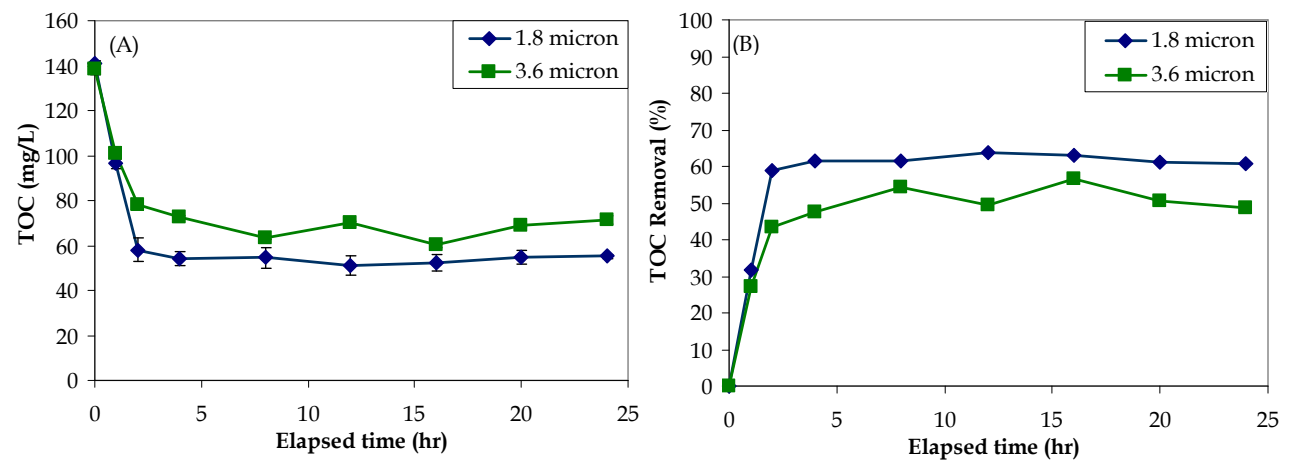

Fig. 8. Effect of $\mathrm{SnO}_{2}$ layer thickness on TOC removal (A) and TOC removal efficiency (B) in continuous restaurant wastewater treatment by using of $\mathrm{SnO}_{2} / \mathrm{Ir} / \mathrm{Ti}$ electrode and current density of $5 \mathrm{~mA} / \mathrm{cm}^{2}$.
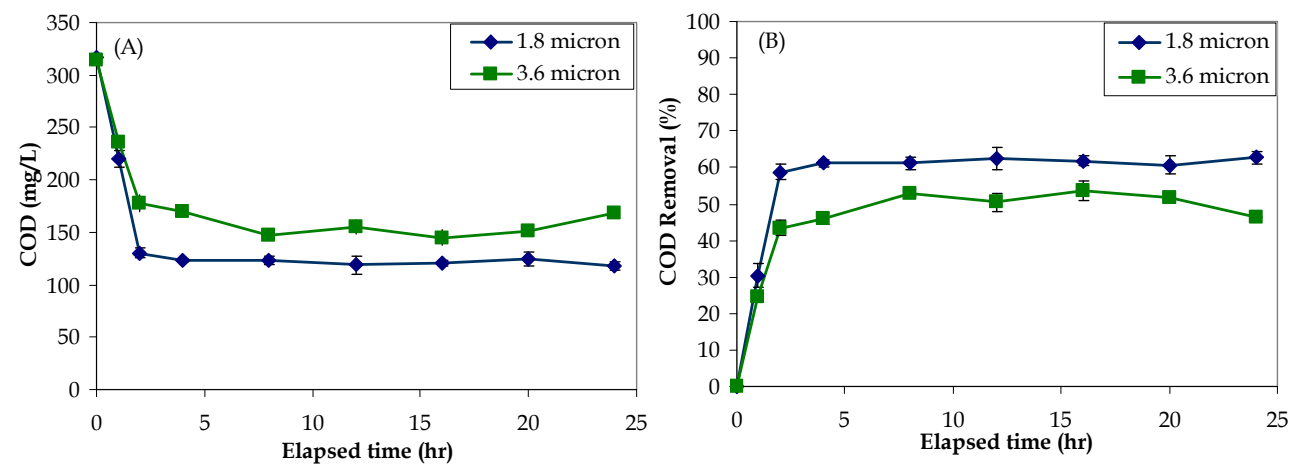

Fig. 9. Effect of $\mathrm{SnO}_{2}$ layer thickness on COD removal (A) and COD removal efficiency (B) in continuous restaurant wastewater treatment by using of $\mathrm{SnO}_{2} / \mathrm{Ir} / \mathrm{Ti}$ electrode and current density $5 \mathrm{~mA} / \mathrm{cm}^{2}$

\subsection{Color removal of pulp and paper mill wastewater by electrochemical incineration} Pulp and paper mill are considered as high water consumption and high wastewater discharge. The pollutants in pulp and paper mill industry are mainly presented in form of high-strength chemical oxygen demand (COD) and biochemical oxygen demand (BOD). Generally, the high-strength BOD and COD are totally removed in biological wastewater treatment unit. The high-strength color from lignin in pulp mill effluent is big problem for pulp and paper mill due to requirement of advanced treatment process with high investment and operating cost. In this chapter, the case study of high efficiency color removal by electrochemical incineration in pulp and paper mill wastewater treatment is explained. The electrochemical incineration is obtained with continuous electrochemical oxidation in a series of 4-simple 3-electrode electrochemical reactor with 5 liters of capacity. The $\mathrm{Ti} / \mathrm{IrO}_{2}-\mathrm{RuO}_{2}$ mixed oxide electrodes were used as anode, the $316 \mathrm{~L}$ stainless steel was used as cathode. The pulp and paper effluent is fed to the reactor by peristaltic pump and the effluent was collected at sample trap. The apparatus is presented in Figure 10. 


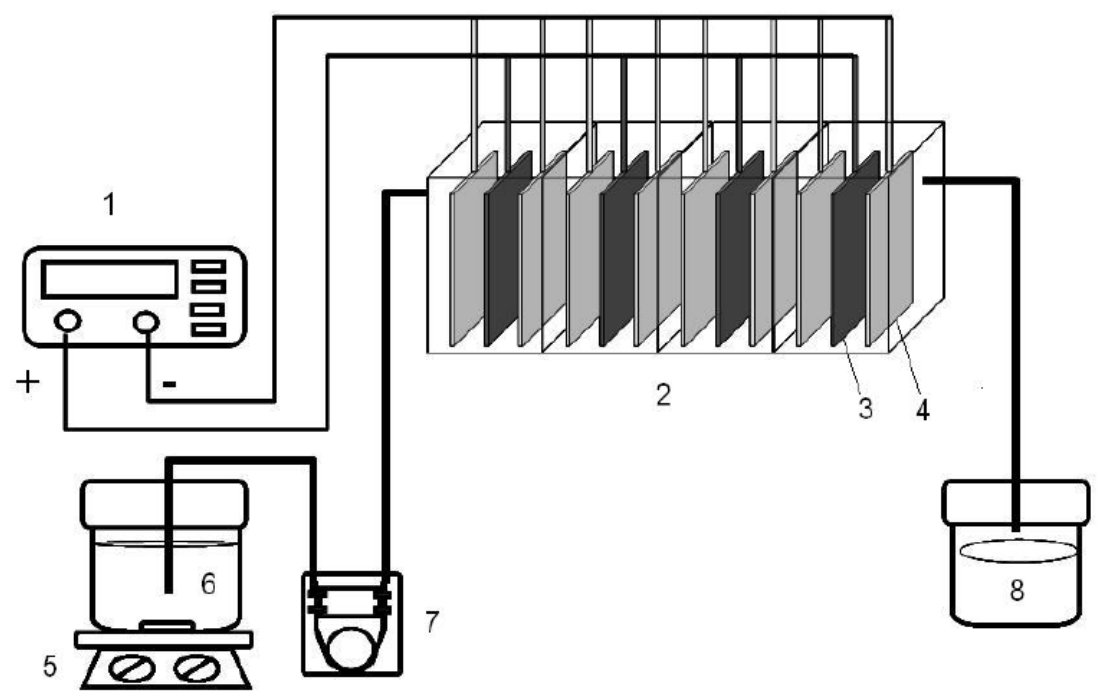

1) Power supply, 2) Electrochemical reactor set, 3) Mixed oxide anode, 4) Stainless steel cathode, 5) Magnetic stirrer, 6) Feed reservoir, 7) Peristaltic pump and 8) Sample trap

Fig. 10. Schematic diagrams of continuous electrochemical oxidation apparatus

Figure 11 show that electrochemical incineration is a powerful tool for color removal from pulp mill wastewater. The results presented that the color substrates in pulp mill effluent was immediately removed. The wastewater color was reduced from 938 Unit Pt/Co to 10-45 Unit Pt/Co or 95-99 \% removal that has very good advantage over conventional biological wastewater treatment process that takes more that 24 hour for reducing pulp mill effluent color from 1,500 to 1,100 Unit Pt/Co. Figure 12 presents the pulp mill at various treatment time for different residence time after started electrochemical incineration process. It is clearly that electrochemical incineration is suitable for breaking color substrates in high color strength wastewater.
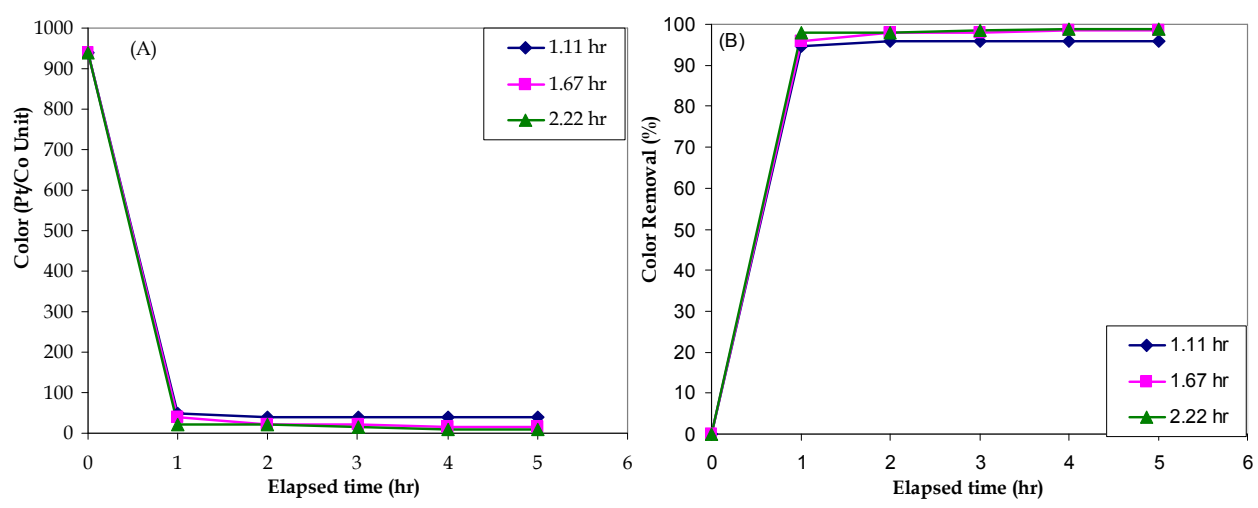

Fig. 11. Influence of treatment time on pulp mill effluent color removal by electrochemical incineration (A) Wastewater color and (B) Color removal efficiency. 


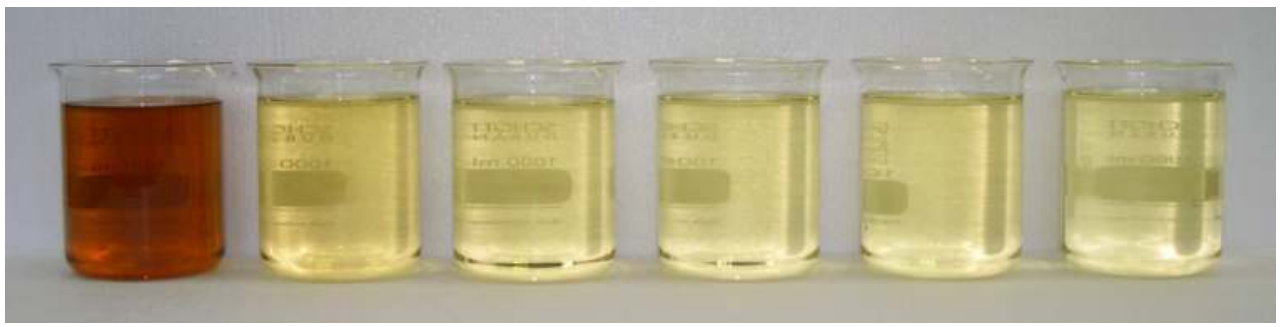

(A)

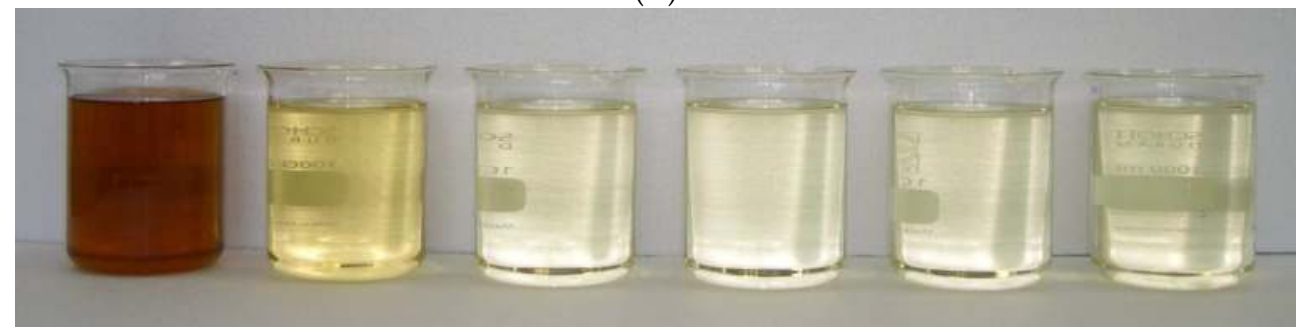

(B)

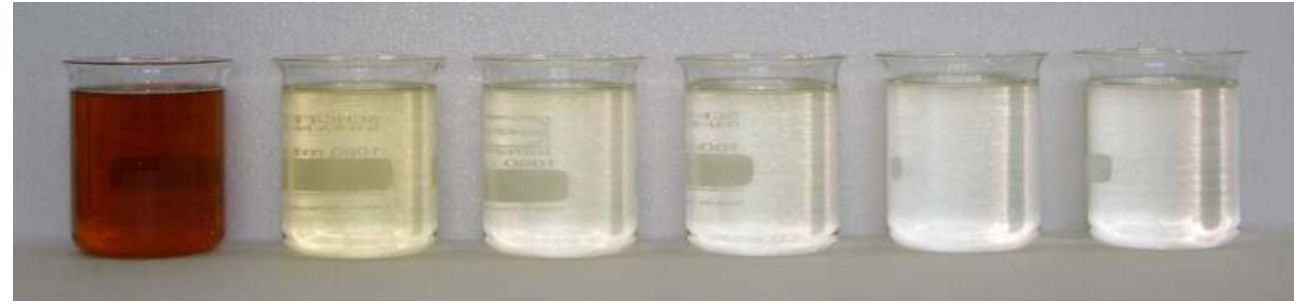

(C)

Fig. 12. Electrochemical incineration of pulp mill effluent (A) Residence time of $1.1 \mathrm{hr}$, Anode-cathode distance of $1.2 \mathrm{~cm}$, Treatment cost of $0.175 \mathrm{USD} / \mathrm{m}^{3}$ and Color removal efficiency of 96\%, (B) Residence time of $1.67 \mathrm{hr}$, Anode-cathode distance of $1.2 \mathrm{~cm}$, Treatment cost of $0.255 \mathrm{USD} / \mathrm{m}^{3}$ and Color removal efficiency of $98 \%$ and (C) Residence time of $2.22 \mathrm{hr}$, Anode-cathode distance of $1.2 \mathrm{~cm}$, Treatment cost of $0.315 \mathrm{USD} / \mathrm{m}^{3}$ and Color removal efficiency of $99 \%$

\section{Prospect \& conclusion}

Water treatment by electricity was used for several years, but electrochemical water or wastewater technologies are not yet a mature application in commercial scale by the limitation of relatively high capital investment and the expensive electricity supply. Nowadays, there are increasing on standard for water discharge and limitation of water resource that makes electrochemical treatment comparable with other water and wastewater treatment technologies. However, to mature the electrochemical water and wastewater treatment there are some requirements need to be fulfilled. SWOT (Strengths, Weaknesses, Opportunities and Threats) is commonly used for business analysis of internal and external factors that should support and sustain or collapse business project (Pinson, 2008). SWOT could help to pin point and predominate advantages of electrochemical technology over 
conventional technologies and drown out disadvantages. Side reactions are a killing trap of electrochemical technology that limits the efficiency of electrochemical systems. In electrochemical incineration, specific coating materials need to be developed to decrease side reaction and to promote desired reaction for attractive benefit and return of investment. During past two decades there are some development in coating technology such as chemical vapor deposition and thermal spray coating that should support the electrode fabrication with appreciate on both constant coating layer and long service life that will response to good return of investment. Electrochemical reactor design is big challenges in electrochemical technology due to it will response on mass transfer during operation. The lack of mass transfer and current distribution in electrochemical reactor will collapse all advantages of electrochemical technology in the battle of technologies.

\section{References}

Azzam, M.O., Tahboub, Y. and Al-Tarazi, M. (1999). Effect of counter electrode material on the anodic destruction of $4-\mathrm{Cl}$ phenol solution, Process Safety and Environmental Protection, Vol 77, N B4, pp 219-226, ISSN 0957-5820

Canizares, P.; Saez, C.; Lobato, J.; Rodrigo, M. A. (2004). Electrochemical treatment of 2,4dinitrophenol aqueous wastes using boron-doped diamond anodes: Part II. Influence of waste characteristics and operating conditions. Electrochimica Acta, Vol 49, N²6, pp 4641-4650,(2004), ISSN 0013-4686

Chen, G. (2004) Electrochemical technologies in wastewater treatment. Separation and Purification Technology, Vol 38, N 1, pp 11-41, ISSN 1383-5866

Chen, X., Chen, G. and Yue, P.L. (2000). Separation of pollutants from restaurant wastewater by electrocoagulation. Separation and Purification Technology, Vol 19, N 1-2, pp 5-76, (2000), ISSN 1383-5866

Comninellis, C. (1994). Electrocatalysis in the electrochemical conversion/ combustion of organic pollutants for waste water treatment. Electrochimica Acta. Vol. 39, No. 11/12, pp. 1857-1862

Comninellis, C. and Nerini, A. (1995). Anodic oxidation of phenol in the presence of $\mathrm{NaCl}$ for wastewater treatment. Journal of Applied Electrochemistry ,Vol. 25, №1, pp 23-28, (1995), ISSN 0021-891

Comninellis, C. and Vercesi, G. P. (1991). Characterization of DSA ${ }^{\circledR}$-type oxygen evolving electrodes. Choice of a Coating. Journal of Applied Electrochemistry, Vol 21, $\mathrm{N}^{\circ} 4$, pp 335-45, (1991), ISSN 0021-891X

Couper, A. Mottram; Pletcher, Derek; Walsh, Frank C.. (1990). Electrode materials for electrosynthesis. Chemical Reviews (Washington, DC, United States), Vol 90, N 5, pp 837-65, (1990), ISSN 0009-2665

Diniz, A. V.; Ferreira, N. G.; Corat, E. J.; Trava-Airoldi, V. J. (2003). Efficiency study of perforated diamond electrodes for organic compounds oxidation process. Diamond and Related Materials, Vol 12, N³-7, pp 577-582, (2003), ISSN 0925-9635

Fernandes, A.; Morao, A.; Magrinho, M.; Lopes, A.; Goncalves, I. (2004). Electrochemical degradation of C. I. Acid Orange 7. Dyes and Pigments ,Vol 61, N³, pp 287-296, (2004), ISSN 0143-7208 
Grimm, J. et al. (1998). Sol-gel film preparation electrodes for the electrocatalytic oxidation of organic pollutants in water. Desalination Vol. 115, N³, pp. 295-302, ISSN 00119164.

Hanze, M., Harremës, P., Jansen, J. C. and Arvin, E. (1995). Wastewater Treatment: Biological and Chemical Processes. Springer, CAN 127:298091, Berlin, Germany

http://www.environmental-center.com/articles/article1149/ article1149.htm

Kapałka, A., Fóti, G. and Comninellis, C. (2009). Basic Principles of the Electrochemical Mineralization of Organic Pollutants for Wastewater Treatment.. Journal of Applied Electrochemistry, Vol 40, № 12, pp 2203, (2010), ISSN 0021-891X

Kesselman J. M., Weres O., Lewis N. S., Hoffmann M. R. (1997). Electrochemical Production of Hydroxyl Radical at Polycrystalline $\mathrm{Nb}$-Doped $\mathrm{TiO}_{2}$ Electrodes and Estimation of the Partitioning between Hydroxyl Radical and Direct Hole Oxidation Pathways. Journal of Physical Chemistry B, Vol. 101, N 14, pp 2637-2643, ISSN 1089-5647

Klamklang, S. (2006). Restaurant wasterwater treatment by electrochemical oxidation in continuous process. Chulalongkorn University Ph.D. Dissertation, ISBN 974-14-3476-6, Bangkok, Thailand

Klamklang, S. (2007). Restaurant wasterwater treatment by electrochemical oxidation in continuous process. Institut National Polytechnique de Toulouse Dissertation,. ISBN 974-14-3476-6, Toulouse, France

Klamklang, S. Vergnes, H., Secocq, F., Pruksathorn, K., Duverneuil, P. and Damronglerd, S. (2010). Deposition of tin oxide, iridium and iridium oxide films by metal-organic chemical vapor deposition for electrochemical wastewater treatment. Journal of Applied Electrochemistry, Vol 40, N 5, pp 997-1004, (2010), ISSN 0021-891X

Kuhn, A. T. (1971). Electrolytic decomposition of cyanides, phenols and thiocyanates in effluents streams-a literature review. Journal of Applied Chemistry \& Biotechnology, Vol 21, N², pp 29-34 Journal; General Review (1971), ISSN 0375-9210

Lissens, G.; Pieters, J.; Verhaege, M.; Pinoy, L.; Verstraete, W. (2003). Electrochemical degradation of surfactants by intermediates of water discharge at carbon-based electrodes. Electrochimica Acta ,Vol. 48, N 12, pp 1655-1663, (2003 ), ISSN 00134686

Morão, A., Lopes, A. Pessoa de Amorimb, M. T. and Gonçalves, I. C. (2004). Degradation of mixtures of phenols using boron doped diamond electrodes for wastewater treatment. Electrochimica Acta, Vol 49, N 9-10, pp 1587-1595, (2004), ISSN 00134686

Panizza, M. and Cerisola, G. (2005). Application of diamond electrodes to electrochemical processes. Electrochimica Acta, Vol 51, N², pp 191-199, (2005), ISSN: 0013-4686

Pinson, L. (2008). Anatomy of a Business Plan, 7th Edtion.: Out of Your Mind and Into Marketplace, ISBN 0-944205-35-6 California, USA

Reemtsma, T. and Jekel, M.( 2006). Organic Pollutants in the Water Cycle. Wiley-VCH, ISBN 3527-31297-8, Weinheim, Germany

Stucki, S., Kötz, R., Carcer, B. and Suter, W. (1991). Electrochemical waste water treatment using high overvoltage anodes Part II: Anode performance and applications. Journal of Applied Electrochemistry Vol. 21, N² 2, pp 99-104, (1991), ISSN 0021-891X 
Vercesi, G. et al. (1991). Characterization of DSA-type oxygen evolving electrodes. Choice of base metal. Thermochimica Acta, Vol 176, pp 31-47, (1991), ISSN 0040-6031 


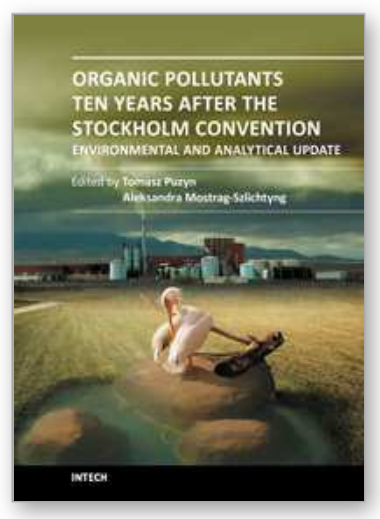

\section{Organic Pollutants Ten Years After the Stockholm Convention - Environmental and Analytical Update}

Edited by Dr. Tomasz Puzyn

ISBN 978-953-307-917-2

Hard cover, 472 pages

Publisher InTech

Published online 24, February, 2012

Published in print edition February, 2012

Ten years after coming into force of the Stockholm Convention on Persistent Organic Pollutants (POPs), a wide range of organic chemicals (industrial formulations, plant protection products, pharmaceuticals and personal care products, etc.) still poses the highest priority environmental hazard. The broadening of knowledge of organic pollutants (OPs) environmental fate and effects, as well as the decontamination techniques, is accompanied by an increase in significance of certain pollution sources (e.g. sewage sludge and dredged sediments application, textile industry), associated with a potential generation of new dangers for humans and natural ecosystems. The present book addresses these aspects, especially in the light of Organic Pollutants risk assessment as well as the practical application of novel analytical methods and techniques for removing OPs from the environment. Providing analytical and environmental update, this contribution can be particularly valuable for engineers and environmental scientists.

\section{How to reference}

In order to correctly reference this scholarly work, feel free to copy and paste the following:

Songsak Klamklang, Hugues Vergnes, Kejvalee Pruksathorn and Somsak Damronglerd (2012).

Electrochemical Incineration of Organic Pollutants for Wastewater Treatment: Past, Present and Prospect, Organic Pollutants Ten Years After the Stockholm Convention - Environmental and Analytical Update, Dr. Tomasz Puzyn (Ed.), ISBN: 978-953-307-917-2, InTech, Available from:

http://www.intechopen.com/books/organic-pollutants-ten-years-after-the-stockholm-convention-environmentaland-analytical-update/electrochemical-incineration-of-organic-pollutants-for-wastewater-treatment-pastpresent-and-prospec

\section{INTECH}

open science | open minds

\section{InTech Europe}

University Campus STeP Ri

Slavka Krautzeka 83/A

51000 Rijeka, Croatia

Phone: +385 (51) 770447

Fax: +385 (51) 686166

www.intechopen.com

\section{InTech China}

Unit 405, Office Block, Hotel Equatorial Shanghai

No.65, Yan An Road (West), Shanghai, 200040, China 中国上海市延安西路65号上海国际贵都大饭店办公楼 405 单元

Phone: +86-21-62489820

Fax: +86-21-62489821 
(C) 2012 The Author(s). Licensee IntechOpen. This is an open access article distributed under the terms of the Creative Commons Attribution 3.0 License, which permits unrestricted use, distribution, and reproduction in any medium, provided the original work is properly cited. 